\title{
EVALUASI KESESUAIAN DOSIS PASIEN PEDIATRIK DIARE AKUT DI RUANG RAWAT INAP RSUD KRATON PERIODE JANUARI-DESEMBER 2019
}

\section{EVALUATION OF THE SUITABILITY OF THE DOSAGE OF PEDIATRIC PATIENTS WITH ACUTE DIARRHEA IN THE RSUD KRATON INPATIENT ROOM FOR THE JANUARY - DECEMBER 2019 PERIOD}

\author{
Ayu Orimpa Nia Sekar Tatik, Ainun Muthoharoh, Wulan Agustin Ningrum, \\ Yulian Wahyu Permadi \\ Universitas Muhammadiyah Pekajangan Pekalongan \\ Jl. Raya Ambokembang No. 08 Pekajangan-Pekalongan \\ E-mail: ayu.orimpa@gmail.com Telp: 085799066643
}

Submitted : 29 Oktober 2020 Reviewed : 13 Februari 2021 Accepted : 24 Maret 2021

\begin{abstract}
ABSTRAK
Diare merupakan penyebab utama morbiditas dan motilitas di kalangan anak - anak kurang dari 5 tahun. Perbedaan karakteristik yang mempengaruhi farmakokinetik dan farmakodinamik suatu obat yang dapat menimbulkan reaksi obat yang tidak dikehendaki seperti grey baby syndrome sehingga hal penting yang harus diperhatikan untuk pediatrik adalah dosis yang optimal. Tujuan dari penelitian ini adalah untuk mengetahui analisis kesesuaian dosis pada pasien pediatrik diare akut rawat inap di RSUD Kraton periode Januari-Desember 2019. Metode yang digunakan pada penelitian ini bersifat deskriptif dengan menggunakan rancangan retrospektif dengan pengambilan sampel dari rekam medis berdasarkan teknik probability sampling dengan cara systematic sampling. Sampel yang digunakan sebanyak 85 sampel. Jenis-jenis obat yang digunakan adalah elektrolit, probiotik, suplemen, antiemetik, antibiotik, antipiretik, analgesik dan antiulserasi. Kesesuaian dosis elektrolit berdasarkan literatur yang digunakan berupa Drug Information Handbook $19^{\text {th }}$ Editiion, Informasi Spesialit Obat, MIMS, Neonatal Pediatric Drug Dose dan Standard Treatment Guideline sebanyak $100 \%$ sesuai, zink sebanyak $68,2 \%$, probiotik sebanyak $100 \%$ sesuai, antibiotik terdapat $58,8 \%$ dosis yang sesuai, analgesik sebanyak $10,6 \%$ dosis yang sesuai, antiemetik berupa domperidone sirup sebanyak $12,9 \%$ dosis yang sesuai, antipiretik berupa parasetamol sebanyak $56,5 \%$, antiulserasi berupa polysilen ${ }^{\circledR}$ terdapat $5,9 \%$ dosis yang sesuai. Dari penelitian ini diharapkan agar pemberiaan dosis pada pasien pediatrik untuk lebih tepat serta memperbanyak literatur atau referensi dalam mempertimbangkan pemberian dosis pediatrik.
\end{abstract}

Kata kunci: diare akut, kesesuaian dosis, pediatric

\section{ABSTRACT}

Diarrhea is the leading cause of morbidity and motility among children less than five years old. Differences in characteristics can affect pharmacokinetics and pharmacodynamics drugs that can cause adverse drug reactions such as grey baby syndrome. The important thing to note for pediatricians is the optimal dose. This study aimed to determine the analysis of dose conformity in pediatric patients with acute diarrhea hospitalized at Kraton Regional Public Hospital in January-December 2019. The method used in this study was descriptive by using a retrospective design 
with sampling from the medical record based on probability sampling technique with systematic sampling. Diarrhea is the leading cause of morbidity and motility among children less than five years old. Differences in characteristics can affect pharmacokinetics and pharmacodynamics drugs that can cause adverse drug reactions such as grey baby syndrome. The important thing to note for pediatricians is the optimal dose. This study aimed to determine the analysis of dose conformity in pediatric patients with acute diarrhea hospitalized at Kraton Regional Public Hospital in January-December 2019. The method used in this study was descriptive by using a retrospective design with sampling from the medical record based on probability sampling technique with systematic sampling. Eighty-five samples were used. The drugs used were electrolytes, probiotics, supplements, antiemetics, antibiotics, antipyretics, analgesics, and anti ulcerative. The dose conformity of the electrolyte dose based on the literature used as much as $100 \%$ was appropriate, $68,2 \%$ dose of zink were appropriate, probiotics as much as $100 \%$ was appropriate, $58,8 \%$ antibiotic dose was appropriate. Analgesics 10,6\%, antiemetic (domperidone syrup) 12,9\%, antipyretic (paracetamol) 56,5\%, and anti ulcerative (polysilane) 5,9\% were appropriate dose. This study expects that dose administration in pediatric patients is more precise and improves literature or reference in considering pediatric dosing. This study expects that dose administration in pediatric patients is more precise and improves literature or reference in considering pediatric dosing.

Keywords: acute diarrhea, dose conformity, pediatric

\author{
Penulis Korespondensi : \\ Ayu Orimpa Nia Sekar Tatik \\ Universitas Muhammadiyah Pekajangan Pekalongan \\ Jl. Raya Ambokembang No. 08 Pekajangan-Pekalongan \\ E-mail: ayu.orimpa@gmail.com Telp: 085799066643
}

\title{
PENDAHULUAN
}

Penggunaan obat dengan dosis yang berlebih ataupun dosis yang kurang adalah salah satu ciri penggunaan obat yang tidak rasional sehingga dapat menyebabkan kegagalan dalam terapi obat pada pasien. Diare akut merupakan buang air besar dengan frekuensi yang meningkat dan bentuk tinja yang lembek atau cair dan berlangsung dalam waktu kurang dari 2 minggu. Berdasarkan penyakit menular, diare adalah penyebab kematian peringkat ke-3 setelah TBC dan pneumonia (Ariani, 2017). Penyakit diare merupakan penyakit endemis di Indonesia dan penyakit potensial kejadian luar biasa (KLB) yang sering disertai kematian (Kemenkes RI, 2015).

Anak-anak merupakan masa yang paling cepat mengalami pertumbuhan dan perkembangan, sehingga terapi obat pada pasien pediatrik berbeda dengan terapi obat pada pasien dewasa karena adanya perbedaan farmakokinetik dan farmakodinamik suatu obat (Kustantinah, dkk, 2009). Diare pada anak sering disebabkan karena adanya infeksi kuman dan serangan bakteri lain yang jumlahnya berlebih dan patogenik. Penatalaksanaan diare akut pada anak menurut World Gastroenterology Organisation Tahun 2012 terdiri dari rehidrasi oral, terapi suplemen zink, diet, probiotik dan antibiotika. Menurut penelitian dari Septiani (2015) bahwa terapi diare untuk pediatrik dengan menggunakan zink, probiotik, serta antibiotik. Kesesuaian zink mengalami tepat dosis sebanyak 76,81\%, kesesuaian antibiotik mengalami tepat dosis sebanyak $4,35 \%$, kesesuaian probiotik mengalami tepat dosis sebanyak 14,50\%. Penelitian menurut Ardyanti (2018) mengenai terapi antibioitik diare akut pada anak dalam pemberiaan antibioitik amoksisilin terdapat ketidaksesuaian 
dosis (overdose) sebanyak 6 pasien sehingga dalam hal ini dapat menyebabkan efek samping terhadap penderita sehingga hal penting yang harus diperhatikan untuk pediatrik adalah dosis yang optimal atau kesesuaian dosis untuk mencapai efek terapi yang maksimal dan dapat mengurangi angka kejadian ketidak optimalnya terapi.

Berdasarkan latar belakang di atas serta studi pendahuluan yang dilakukan, diare akut merupakan penyakit saluran pencernaan yang paling banyak terjadi di RSUD Kraton Kabupaten Pekalongan yaitu sebanyak 328 pasien sehingga hal ini yang mendorong peneliti untuk melakukan penelitian tentang evaluasi kesesuaian dosis untuk terapi pengobatan diare akut pada pasien pediatrik.

\section{METODE PENELITIAN}

Metode yang digunakan pada penelitian ini bersifat deskriptif dengan menggunakan rancangan retrospektif dengan pengambilan sampel dari rekam medis berdasarkan teknik probability sampling dengan cara systematic sampling. Alat yang digunakan adalah lembar pengambilan data, data hasil laboratorium pasien, lembar evaluasi kesesuaian dosis dan beberapa daftar panduan referensi DIH (Drug Infromation Handbook 20 th Ed), ISO (Informasi Spesialit Obat) volume 51, MIMS 2019, Neonatal and Pediatric Drug Doses 2014 dan Standard Treatment Guideliness $6^{\text {th }}$.

Kriteria inklusi dari penelitian ini yaitu rekam medik, pasien pediatrik umur 0-14 tahun, pasien pediatrik yang menjalani rawat inap $\geq 3$ hari baik pembayaran secara umum atau BPJS, pasien pediatrik yang hanya menderita diare akut dan dengan penyakit penyerta yang menjalani pengobatan di ruang rawat inap anak, pasien pediatrik yang telah menyelesaikan pengobatan hingga dinyatakan sembuh dan diperbolehkan pulang oleh dokter, dan pasien pediatrik dengan data rekam medik yang lengkap berupa nama pasien, alamat, tempat tanggal lahir, berat badan, nomer rekam medik, usia, lama perawatan dan penyakit diare dengan atau tanpa penyakit penyerta. Sedangkan untuk kriteria eksklusi berupa data pasien pediatrik yang tidak menderita diare akut yang menjalani rawat inap di RSUD Kraton, data pasien yang pulang paksa serta pasien yang meninggal dalam perawatan dan data rekam medik yang kurang lengkap.

\section{Jalannya Penelitian}

1. Tahap penentuan sampel penelitian

Pada tahap ini sudah diketahui jumlah populasi pasien anak di Rumah Sakit Umum Daerah Kraton, selanjutnya dilakukan pengolahan data. Pengambilan sampel dalam penelitian ini secara acak (probability sampling) dengan teknik systematic sampling. Jumlah sampel diambil dengan menggunakan rumus perhitungan slovin:

$$
\mathrm{n}=\frac{\mathrm{N}}{1+\mathrm{N}(\mathrm{e})^{2}}
$$

Sehingga diperoleh sampel sebanyak 76,63. dibulatkan menjadi 77 sampel. Dalam pengambilan sampel perlu dilakukan penambahan $10 \%$ untuk mengantisipasi adanya sampel yang terekslusi banyak sehingga sampel yang diambil dalam penelitian ini sebanyak 85 sampel.

2. Tahap pengambilan data

Pengambilan data berdasarkan data rekam medik pasien pada tahun 2019 yang dilakukan dengan Teknik Sampling probability dengan cara systematic sampling. Kemudian, di evaluasi kesesuaian dosis meliputi identitas pasien yang lengkap, nomer 
rekam medik, penggunaan obat, dosis yang mengacu pada literatur, rute pemberian dan frekuensi penggunaan obat yang kemudian ditulis dalam lampiran data yang sudah dibuat. Data yang sudah diperoleh dianalisis.

\section{Analisis Data}

Analisis data yang digunakan yaitu dengan univariate dengan mendiskripsikan karakteristik setiap variabel yang diteliti, dengan menghasilkan presentase setiap variabel yang diteliti dan analisis yang akan dilakukan akan menghasilkan distribusi frekuensi. Dosis dikatakan sesuai dalam hal ini apabila dosis obat yang diteliti baik dosis 1x ataupun 1 hari sesuai dengan literatur yang digunakan untuk acuan. Selanjutnya, dari hasil yang diperoleh dijelaskan dalam pembahasan yang kemudian ditarik kesimpulan.

\section{HASIL DAN PEMBAHASAN}

Penelitian ini dilakukan di RSUD Kraton Kabupaten Pekalongan pada bulan Maret-Mei 2020. Metode dalam penelitian ini bersifat deskriptif dengan menggunakan rancangan studi retrospektif. Berdasarkan hasil studi pendahuluan di RSUD Kraton Kabupaten Pekalongan, jumlah pasien diare akut anak yang di rawat inap pada tahun 2019 sebanyak 328 pasien. Menurut Gay \& Diehl berpendapat bahwa sampel haruslah sebesar-besarnya yang berarti bahwa semakin banyak sampel yang diambil maka akan semakin representative. Namun, ukuran sampel yang dapat diterima tergantung dari jenis penelitiannya (Amirullah, 2015). Sehingga peneliti mengambil sampel sebanyak 85 pasien dari 328 rekam medis pasien yang memenuhi kriteria inklusi yaitu mencantumkan nama pasien, alamat, tempat tanggal lahir, berat badan, nomer rekam medik, usia, lama perawatan dan penyakit diare dengan atau tanpa penyakit penyerta.

Penelitian ini dilakukan di ruang Filling Rekam Medis RSUD Kraton Kabupaten Pekalongan dengan mengambil sampel sebanyak 85 rekam medis pada tahun 2019 secara acak sistematik. Jika rekam medis yang diambil tidak sesuai dengan kriteria inklusi maka diambil kembali rekam medis yang lain hingga diperoleh data rekam medis yang sesuai dengan kriteria inklusi sampai terpenuhi jumlah sampel yang dikehendaki. Kemudian, mengkaji dan menganalisis pengobatan pasien terkait kelengkapan identitas pasien dan dosis obat yang kemudian analisis hasil diperoleh dalam bentuk persentase disetiap variabelnya. Kesesuaian dosis yang digunakan berdasarkan pedoman yang digunakan yaitu DIH (Drug Information Handbook $20^{\text {th }} \mathrm{Ed}$ ), ISO (Informasi Spesialit Obat) volume 51, MIMS 2019, Neonatal and Pediatric Drug Doses 2014 dan Standard Tretment Guidelines $6^{\text {th }}$. Berdasarkan hasil analisis dari 85 rekam medis, diketahui bahwa ada beberapa obat yang dosisnya belum sesuai dengan pedoman atau literatur yang digunakan dalam penelitiaan:

\section{A. Karakteristik sampel}

Penelitian ini dengan menggunakan 85 sampel pasien pediatrik diare cair akut di RSUD Kraton Kabupaten Pekalongan terdiri dari dua jenis kelamin yaitu laki-laki dan perempuan dengan data dapat dilihat pada Tabel I:

Tabel I. Karakteristik sampel berdasarkan jenis kelamin

\begin{tabular}{ccc}
\hline Jenis Kelamin & Jumlah $(\mathbf{n})$ & Persentase $(\boldsymbol{\%})$ \\
\hline Laki-laki & 61 & 71,8 \\
Perempuan & 24 & 28,2 \\
\hline Total & 85 & 100 \\
\hline & & (Data diolah, 2020)
\end{tabular}

Berdasarkan data diatas dapat diketahui bahwa sebagian besar pasien pediatrik diare akut berjenis kelamin laki-laki sebanyak 61 pasien. Penelitian menurut Purnamasari, dkk (2014) dan Septiani, dkk (2015) menyatakan bahwa jenis kelamin laki-laki yang paling banyak menderita diare akut daripada yang berjenis perempuan. 
Menurut Dwiperwantoro dkk menyebutkan penyebab anak laki-laki lebih sering menderita diare akut adalah karena anak laki-laki tingkat aktifitasnya lebih banyak, mulai mengeksplorasi lingkungan dan lebih sering kontak dengan daerah yang kotor sehingga lebih mudah terserang mikroorganisme penyebab diare akut. Penelitian menurut Korompis dkk (2013) penderita penyakit diare akut paling banyak laki-laki, aktivitas fisik yang banyak pada laki-laki remaja dan dewasa dapat membuat kondisi fisik tubuh cepat mengalami penurunan kekebalan tubuh, sehingga rentan terkena penyakit seperti diare akut. Berdasarkan Tabel 1 dilihat dari banyaknya angka tersebut bukan berarti pasien laki-laki lebih bersiko terkena diare cair akut dibandingkan dengan perempuan, akan tetapi laki-laki dan perempuan mempunyai faktor resiko yang sama terhadap penyakit diare.

Karakteristik sampel yang selanjutnya yaitu berdasarkan usia pasien pediatrik diare akut di RSUD Kraton Kabupaten Pekalongan berkisar antara 1 bulan-14 tahun. Data karakteristik usia responden dipaparkan pada Tabel II:

Tabel II. Karakteristik sampel berdasarkan usia

\begin{tabular}{ccc}
\hline Usia & Jumlah (n) & Persentase (\%) \\
\hline $1-12$ bulan & 47 & 55,3 \\
$2-14$ tahun & 38 & 44,7 \\
\hline Total & 85 & 100 \\
\hline & & (Data diolah, 2020)
\end{tabular}

Berdasarkan data pada Tabel II, menunjukkan bahwa sampel yang diteliti sebagian besar berusia 1 bulan-12 bulan sebanyak 47 pasien, usia tersebut dikategorikan sebagai bayi menurut "The Brithish Pediatric Association (BPA)" sedangkan pada usia 2 tahun14 tahun sebagai anak. Masa bayi dan anak merupakan periode pertumbuhan dan perkembangan yang sangat pesat, sehingga penggunaan obat untuk anak merupakan hal khusus yang terkait dengan perbedaan laju perkembangan organ, sistem enzim yang bertanggung jawab terhadap metabolisme dan ekskresi obat (Kustantinah, dkk., 2009). Penelitian menurut Korompis dkk (2013) penderita penyakit diare akut terjadi pada umur 1-5 tahun, pada usia tersebut merupakan kelompok anak yang mulai aktif bermain di lingkungan yang kotor dan hidup yang kurang bersih sehingga rentan terkena infeksi penyakit terutama diare.

\section{B. Kelengkapan Identitas Pasien}

Kelengkapan identitas pasien sangat penting dalam proses pengobatan. Analisis identitas pasien ini berupa nama, umur, jenis kelamin, alamat, nomor rekam medis, berat badan, tempat tanggal lahir dan lama perawatan dapat dilihat pada Tabel III.

Tabel III. Kelengkapan Identitas Pasien

\begin{tabular}{ccc}
\hline Identitas pasien & Jumlah (n) & Persentase (\%) \\
\hline Lengkap & 85 & 100 \\
Tidak Lengkap & 0 & 0 \\
\hline Total & 85 & 100 \\
\hline & & (Data diolah, 2020)
\end{tabular}

Berdasarkan hasil pada Tabel III dapat diketahui bahwa sampel yang diteliti memiliki kelengkapan identitas sebanyak $100 \%$. Pentingnya dilakukan skrining resep untuk menjamin keamanan dan kemanjuran dari obat yang diberikan pada pasien dan dapat mengoptimalkan efek terapi. Ketidak lengkapan skrining resep dapat mengakibatkan adanya medication eror atau merugikan dan membahayakan pasien khususnya dalam pelayanan pengobatan pasien. 


\section{Pengobatan Pasien Pediatrik Diare Cair Akut di RSUD Kraton Kabupaten Pekalongan}

Berikut merupakan tabel jenis obat-obatan yang diberikan pada pasien pediatrik diare cair akut di RSUD Kraton Kabupaten Pekolongan dapat dilohat pada Tabel IV: Berdasarkan tabel diatas obat-obatan yang digunakan pada pasien pediatrik diare cair akut menurut World Gastroenterology Organization (2012) adalah sebagai berikut:

Tabel IV. Jenis obat-obatan yang diberikan pada pasien pediatrik diare cair akut di RSUD Kraton Kabupaten Pekalongan

\begin{tabular}{|c|c|c|c|}
\hline Kelas Terapi & Nama Obat & $\operatorname{Jumlah}(n)$ & Persentase $(\%)$ \\
\hline \multirow[t]{5}{*}{ Elektrolit } & Oralit/Indoralit & 16 & 18,8 \\
\hline & Infus Ringer Laktat & 61 & 71,8 \\
\hline & Infus D5 1/4 NS & 27 & 31,8 \\
\hline & Infus RD 5\% & 37 & 43,5 \\
\hline & Infus KAEN 3B & 4 & 4,7 \\
\hline \multirow[t]{4}{*}{ Suplemen } & Zink sirup & 67 & 78,8 \\
\hline & Sirup elkana ${ }^{\circledR}$ & 7 & 8,2 \\
\hline & Sanbe plex ${ }^{\circledR}$ & 3 & 3,5 \\
\hline & Sirup imboost ${ }^{\circledR}$ & 1 & 1,2 \\
\hline \multirow[t]{2}{*}{ Probiotik } & Lacto-B $^{\circledR}$ & 32 & 37,6 \\
\hline & Liprolac $^{\circledR}$ & 1 & 1,2 \\
\hline \multirow[t]{2}{*}{ Antiemetik } & Domperidone/sirup vometa $^{\circledR}$ & 30 & 35,3 \\
\hline & Ondasentron & 19 & 23.5 \\
\hline \multirow[t]{9}{*}{ Antibiotik } & Sirup nifudiar ${ }^{\circledR}$ & 45 & 51,8 \\
\hline & Clanexy $^{\circledR}$ & 6 & 7,1 \\
\hline & Cefadroxil & 5 & 5,4 \\
\hline & Ceftriaxone & 1 & 1,2 \\
\hline & Amoxicillin & 2 & 2,4 \\
\hline & Cefixime & 4 & 4,7 \\
\hline & Ampisilin & 5 & 5,9 \\
\hline & Metronidazole & 4 & 4,7 \\
\hline & Cefotaxime & 22 & 27,1 \\
\hline Antipiretik & Parasetamol & 71 & 83,5 \\
\hline Analgesik & Sirup norages $^{\circledR}$ & 12 & 14,1 \\
\hline \multirow[t]{4}{*}{ Antiulserasi } & Ranitidine & 3 & 3,5 \\
\hline & Antasida & 3 & 3,5 \\
\hline & Mylanta $^{\circledR}$ & 2 & 2,4 \\
\hline & Polysilen $^{\circledR}$ & 5 & 5,9 \\
\hline
\end{tabular}

(Data diolah, 2020)

\section{D.Kesesuaian Dosis}

Tepat dosis merupakan pemilihan obat sesuai dengan takaran, pemakaian dan durasi yang sesuai untuk pasien. Analisis pemberian obat berdasarkan parameter tepat dosis dievaluasi pada pasien yang mendapatkan obat dengan kriteria tepat obat (Septiani,.dkk, 2015). Kesesuaian dosis adalah jumlah obat yang diberikan harus dengan jumlah yang sesuai dengan pedoman DIH (Drug Information Handbook $20^{\text {th }}$ ED), ISO (informasi spesialit obat) volume 51, MIMS 2019, Neonatal Pediatric Drug Doses 2014 Dan Standard Treathment Guidelines $6^{\text {th }}$ dalam pemberian terapi penggunaan obat diare akut pada pediatrik di RSUD Kraton Kabupaten Pekalongan. 
Tabel V. Data kesesuaian dosis untuk penggunaan elektrolit pada pasien pediatrik diare cair akut di RSUD Kraton Kabupaten Pekalongan

\begin{tabular}{|c|c|c|c|c|c|c|c|c|c|c|}
\hline \multirow[t]{2}{*}{$\begin{array}{l}\text { kesesuaian } \\
\text { dosis }\end{array}$} & \multicolumn{2}{|c|}{$\begin{array}{c}\text { A } \\
\text { (Drug } \\
\text { Information } \\
\text { Handbook } \\
\text { 19 }^{\text {th }} \text { Edition) }\end{array}$} & \multicolumn{2}{|c|}{$\begin{array}{c}\text { B } \\
\text { (Informasi } \\
\text { Spesialit } \\
\text { Obat) }\end{array}$} & \multicolumn{2}{|c|}{$\begin{array}{c}\text { C } \\
\text { (MIMS) }\end{array}$} & \multicolumn{2}{|c|}{$\begin{array}{c}\text { D } \\
\text { (Neonatal } \\
\text { Pediatric } \\
\text { Drug Dose) }\end{array}$} & \multicolumn{2}{|c|}{$\begin{array}{c}c \text { E } \\
\text { (Standard } \\
\text { Treatment } \\
\text { Guideline) }\end{array}$} \\
\hline & $\mathbf{N}$ & $\%$ & $\mathbf{N}$ & $\%$ & $\mathbf{N}$ & $\%$ & $\mathbf{N}$ & $\%$ & $\mathbf{N}$ & $\%$ \\
\hline Sesuai & 85 & $100 \%$ & 85 & $100 \%$ & 85 & $100 \%$ & 85 & $100 \%$ & 85 & $100 \%$ \\
\hline $\begin{array}{l}\text { Tidak } \\
\text { sesuai }\end{array}$ & 0 & 0 & 0 & 0 & 0 & 0 & 0 & 0 & 0 & 0 \\
\hline Total & 85 & $100 \%$ & 85 & $100 \%$ & 85 & $100 \%$ & 85 & $100 \%$ & 85 & $100 \%$ \\
\hline
\end{tabular}

Berdasarkan data yang diperoleh pada Tabel V dapat diketahui bahwa penggunaan elektrolit di RSUD Kraton Kabupaten Pekalongan dalam kesesuaian dosis terapi diare akut berdasarkan 5 literatur yang digunakan pada pengobatan pasien pediatrik sebanyak 85 diketahui $100 \%$ sesuai.

Pada penelitian ini pasien diberikan oralit apabila pasien memiliki tanda mual muntah, rewel atau gelisah, kesadaran berkurang, mata cekung, cubitan perut kembalinya lambat atau sangat lambat dan haus atau minum dengan lahap atau malas minum atau tidak bisa minum. Pada penelitian menurut Purnamasari (2014) menyatakan bahwa dalam penggunaan elektrolit pasien diare anak sebanyak 12 kasus sesuai, sedangkan penelitian menurut Pertiwi dkk (2017) terapi diare akut penggunaan elektrolit diberikan sesuai dengan standar penanganan diare akut pada anak. Sehingga dalam hal ini dapat disimpulkan bahwa pemberiaan terapi diare berupa elektrolit telah diberikan berdasarkan standar yang sesuai. Elektrolit dapat bermanfaat untuk mengatasi hilangnya cairan pada tubuh untuk mengatasi diare. Kehilangan cairan merupakan komplikasi utama, terutama pada anak-anak dan lanjut usia. Pada kejadian diare akut karena kolera dapat mengalami kehilangan cairan yang mendadak dan syok hipovolemik. Kehilangan cairan melalui feses dapat mengakibatkan hypokalemia dan asidosis metabolik sehingga pemberian elektrolit pada kasus diare merupakan hal yang tepat (Amin, 2015).

Tabel VI. Data kesesuaian dosis suplemen pada pasien pediatrik diare cair akut di RSUD Kraton Kabupaten Pekalongan

\begin{tabular}{|c|c|c|c|c|c|c|c|c|c|c|c|}
\hline \multirow[t]{2}{*}{$\begin{array}{c}\text { Nama } \\
\text { Obat }\end{array}$} & \multirow[t]{2}{*}{$\begin{array}{c}\text { kesesuaian } \\
\text { dosis }\end{array}$} & \multicolumn{2}{|c|}{$\begin{array}{c}\text { A } \\
\text { (Drug } \\
\text { Information } \\
\text { Handbook } \\
\text { 19 }^{\text {th }} \\
\text { Edition) }\end{array}$} & \multicolumn{2}{|c|}{$\begin{array}{c}\text { B } \\
\text { (Informasi } \\
\text { Spesialit } \\
\text { Obat) }\end{array}$} & \multicolumn{2}{|c|}{$\begin{array}{c}\text { C } \\
(\text { MIMS) }\end{array}$} & \multicolumn{2}{|c|}{$\begin{array}{c}\text { D } \\
\text { (Neonatal } \\
\text { Pediatric } \\
\text { Drug } \\
\text { Dose) }\end{array}$} & \multicolumn{2}{|c|}{$\begin{array}{c}\text { E } \\
\text { (Standard } \\
\text { Treatment } \\
\text { Guideline) }\end{array}$} \\
\hline & & $\mathbf{n}$ & $\%$ & $\mathbf{n}$ & $\%$ & $\mathbf{N}$ & $\%$ & $\mathbf{N}$ & $\%$ & $\mathbf{N}$ & $\%$ \\
\hline \multirow{4}{*}{ Zink } & Sesuai & 7 & $8,2 \%$ & 58 & $68,2 \%$ & 58 & $68,2 \%$ & 8 & $9,4 \%$ & 58 & $68,2 \%$ \\
\hline & Tidak sesuai & 60 & $70,6 \%$ & 9 & $10,6 \%$ & 9 & $10,6 \%$ & 59 & $69,4 \%$ & 9 & $10,6 \%$ \\
\hline & $\begin{array}{c}\text { Tidak } \\
\text { mengunakan } \\
\text { obat }\end{array}$ & 18 & $21,2 \%$ & 18 & $21,2 \%$ & 18 & $21,2 \%$ & 18 & $21,2 \%$ & 18 & $21,2 \%$ \\
\hline & Total & 85 & $100 \%$ & 85 & $100 \%$ & 85 & $100 \%$ & 85 & $100 \%$ & 85 & $100 \%$ \\
\hline \multirow{4}{*}{ Elkana $^{\circledR}$} & Sesuai & - & - & 5 & $5,9 \%$ & 3 & $3,5 \%$ & - & - & - & - \\
\hline & Tidak sesuai & - & - & 2 & $2,4 \%$ & 4 & $4,7 \%$ & - & - & - & - \\
\hline & $\begin{array}{c}\text { Tidak } \\
\text { menggunakan } \\
\text { obat }\end{array}$ & - & - & 78 & $91,8 \%$ & 78 & $91,8 \%$ & - & - & - & - \\
\hline & Total & - & - & 85 & $100 \%$ & 85 & $100 \%$ & - & - & - & - \\
\hline Sanbe & Sesuai & - & - & 0 & 0 & 0 & 0 & - & - & - & - \\
\hline
\end{tabular}




\begin{tabular}{|c|c|c|c|c|c|c|c|c|c|c|c|}
\hline \multirow[t]{2}{*}{ plex $^{\circledR}$} & $\begin{array}{c}\text { Tidak sesuai } \\
\text { Tidak } \\
\text { menggunakan } \\
\text { obat }\end{array}$ & - & - & 82 & $96,5 \%$ & 82 & $96,5 \%$ & - & - & - & - \\
\hline & Total & - & - & 85 & $100 \%$ & 85 & $100 \%$ & - & - & - & - \\
\hline \multirow{4}{*}{ Imboost $^{\circledR}$} & Sesuai & - & - & - & - & 0 & 0 & - & - & - & - \\
\hline & Tidak sesuai & - & - & - & - & 1 & $1,2 \%$ & - & - & - & - \\
\hline & $\begin{array}{c}\text { Tidak } \\
\text { menggunakan } \\
\text { obat }\end{array}$ & - & - & - & - & 84 & $98,8 \%$ & - & - & - & - \\
\hline & Total & - & - & - & - & 85 & $100 \%$ & - & - & - & - \\
\hline
\end{tabular}

Keterangan:

(-): tidak menggunakan literatur

Dari hasil penelitian yang telah dilakukan pada Tabel VI diketahui bahwa terapi diare akut pada pasien peditarik di RSUD Kraton Kabupaten Pekalongan dalam pemberian suplemen berupa zink, elkana ${ }^{\circledR}$, sanbe plek $^{\circledR}$ serta imboost $^{\circledR}$. Dari keempat suplemen yang banyak digunakan merupakan zink. Dosis obat dinyatakan sesuai jika besarnya takaran yang diberikan kepada pasien sesuai, pada suplemen zink penentuan kesesuaian dosis menggunakan literatur Standard Treatment Guidelines dosis zink yang sesuai sebesar 58 kasus $(68,2 \%)$. Dari hasil tersebut dapat diketahui bahwa terdapa banyak dosis yang tidak sesuai, ketidaksesuaian ini dikarenakan kakteristik pasien seperti berat badan dan umur dari masing-masing pasien yang dapat mempengaruhi perhitungan dosis. Adapun dosis umum zink untuk anak sebesar sehari $20 \mathrm{mg} /$ zink diberikan selama 10 hari berturut-turut.

Berdasarkan hasil yang diperoleh literatur ISO, MIMS, dan Standard Treatment Guidelines yang bagus untuk dijadikan acuan dalam pemberian dosis zink pada anak. Menurut World Gastroenterologi Organization (WGO) tahun 2012 untuk anak yang menderita diare akut direkomendasikan zink dengan dosis $20 \mathrm{mg} /$ hari diberikan selama 10 hari berturut-turut sedangkan untuk bayi berusia 2 bulan atau lebih dosis zink diberikan $10 \mathrm{mg} /$ hari diberikan selama 10 hari berturut-turut. Suplemen dengan zink dalam dosis yang direkomendasikan dapat mengurangi kejadian diare selama 3 bulan dan mengurangi kematian non-kecelakaan sebanyak 50\%. Faktor resiko untuk terjadinya diare persisten perlu dilakukan adanya pencegahan diare akut melanjut dengan memberikan suplementasi zink bertujuan untuk mencegah diare berulang, melanjut atau peristen. Di negara berkembang, diare persisten menyumbang angka kematian yang tinggi berkisar antara 23\%-70\%. Pada anak dinegara berkembang, salah satu pilar tatalaksana diare akut merupakan dengan pemberian suplementasi zink.

Berdasarkan data penelitian suplemen sanbe plek ${ }^{\circledR}$ dan sirup imboost ${ }^{\circledR}$ merupakan suplemen yang jarang diberikan pada pasien pediatrik diare akut di RSUD Kraton Kabupaten Pekalongan. Suplemen sanbe plek $^{\circledR}$ dalam penentuan kesesuaian dosis berdasarkan literatur hanya menggunakan 2 literatur yaitu Informasi Spesialit Obat (ISO) dan MIMS, dari kedua literatur tersebut dapat diketahui bahwa dosis yang diberikan belum sesuai dengan literatur yang digunakan, ketidaksesuaian ini dikarenaka adanya dosis yang lebih atau kurang dari dosis standar yaitu bayi sebanyak 0,3 $\mathrm{ml}$ sehari dan anak 0,6 ml sehari. Berdasarkan Tabel VI dosis yang tidak sesuai sebanyak 3 pasien $(3,5 \%)$, sedangkan pada suplemen sirup imboost ${ }^{\circledR}$ dalam penentuan kesesuaian dosis berdasarkan literatur hanya menggunakan 1 literatur yaitu MIMS, dari data yang diperoleh diketahui bahwa dosis yang diberikan belum sesuai dengan literatur yang digunakan yaitu sebesar 1 pasien $(1,2 \%)$, ketidaksesuaian ini dikarenakan adanya dosis yang kurang atau lebih dari dosis standar yaitu anak $\leq 6$ tahun $1 / 2-1$ sendok takar 3 kali sehari sedangkan untuk anak $\geq 6$ tahun 3 kali sehari sebanyak $5 \mathrm{ml}$. 
Tabel VII. Data kesesuaia dosis probiotik pada pasien pediatrik diare cair akut di RSUD Kraton Kabupaten Pekalongan

\begin{tabular}{|c|c|c|c|c|c|c|c|c|c|c|}
\hline \multirow[t]{2}{*}{$\begin{array}{l}\text { Kesesuaian } \\
\text { dosis }\end{array}$} & \multicolumn{2}{|c|}{$\begin{array}{c}\text { A } \\
\text { (Drug } \\
\text { Information } \\
\text { Handbook 19 } \\
\text { Edition) }\end{array}$} & \multicolumn{2}{|c|}{$\begin{array}{c}\text { B } \\
\text { (Informasi } \\
\text { Spesialit } \\
\text { Obat) }\end{array}$} & \multicolumn{2}{|c|}{$\begin{array}{c}\mathrm{C} \\
(\mathrm{MIMS})\end{array}$} & \multicolumn{2}{|c|}{$\begin{array}{c}\text { D } \\
\text { (Neonatal } \\
\text { Pediatric } \\
\text { Drug Dose) }\end{array}$} & \multicolumn{2}{|c|}{$\begin{array}{c}\mathrm{E} \\
\text { (Standard } \\
\text { Treatment } \\
\text { Guideline) }\end{array}$} \\
\hline & $\mathbf{n}$ & $\%$ & $\mathbf{N}$ & $\%$ & $\mathbf{N}$ & $\%$ & $\mathbf{N}$ & $\%$ & $\mathbf{N}$ & $\%$ \\
\hline Sesuai & - & - & 85 & $100 \%$ & 85 & $100 \%$ & - & - & - & - \\
\hline $\begin{array}{l}\text { Tidak } \\
\text { sesuai }\end{array}$ & - & - & 0 & 0 & 0 & 0 & - & - & - & - \\
\hline Total & - & - & 85 & $100 \%$ & 85 & $100 \%$ & - & - & - & - \\
\hline
\end{tabular}

Keterangan:

(-): tidak menggunakan literatur

Pada pemberian terapi diare akut berupa probiotik pada pasien pediatrik di RSUD Kraton Kabupaten Pekalongan dilihat pada Tabel VII dapat dilihat bahwa dalam kesesuaian dosis berdasarkan 5 literatur hanya 2 literatur yang ada obat golongan probiotik. Dari literatur tersebut kesesuaian dosis yang digunakan pada 85 sampel diketahui $100 \%$ sesuai.

Menurut literatur Informasi Spesialit Obat (ISO) penggunaan probiotik berupa Lacto- ${ }^{\circledR}{ }^{\circledR}$ untuk anak umur 6-12 tahun 3 sachet/hari sedangkan untuk anak umur $\leq 1$ tahun 2 sachet/hari dan probiotik berupa liprolac digunakan 2 sachet/hari. Literatur MIMS Lacto-B ${ }^{\circledR}$ untuk anak umur 1-12 tahun 3 sachet/hari sedangkan liprolac 2 sachet/hari, adapun menurut penelitian yang lain probiotik pada anak diberikan 2 sachet/hari sehingga dapat disimpulkan bahwa pemberian probiotik pada anak diberikan 2-3 sachet sehari.

Menurut Rahmi, dkk (2015) menyatakan bahwa pada umumnya mikroorganisme probiotik berasal dari kelompok Lactic acid-producing bacteria (LAB) yang dapat mencerna sakarida secara anaerob dan memproduksi asam laktat. Mekanisme kerja dari probiotik belum dapat dijelaskan dengan pasti, akan tetapi diduga dapat merubah lingkungan mikro lumen usus $(\mathrm{pH}$, oksigen) produksi bahan anti mikroba terhadap beberapa patogen usus, kompetisi nutrient, peningktan toleransi pada laktosa, meningkatkan sistem imun, efek antialergi, pencegahan penyakit kardiovaskular, dan pencegahan penyakit kanker. Pemberian probiotik dalam penangan kasus diare merupakan terapi yang tepat karena bermanfaat untuk menjaga keseimbangan mikroflora intestinal dan efektif untuk pencegahan dan pengobatan terhadap berbagai kelainan gastrointestinal seperti diare (Siswidiasari., dkk, 2014).

Tabel VIII. Data kesesuaian dosis antibiotik pasien pediatrik diare cair akut di RSUD Kraton Kabupaten Pekalongan

\begin{tabular}{|c|c|c|c|c|c|c|c|c|c|c|c|}
\hline \multirow[t]{2}{*}{ Nama obat } & \multirow[t]{2}{*}{$\begin{array}{c}\text { kesesuaian } \\
\text { dosis }\end{array}$} & \multicolumn{2}{|c|}{$\begin{array}{c}\text { A } \\
\text { (Drug } \\
\text { Information } \\
\text { Handbook } \\
\text { 19 }^{\text {th }} \\
\text { Edition) } \\
\end{array}$} & \multicolumn{2}{|c|}{$\begin{array}{c}\text { B } \\
\text { (Informasi } \\
\text { Spesialit } \\
\text { Obat) }\end{array}$} & \multicolumn{2}{|c|}{$\begin{array}{c}\text { C } \\
(\text { MIMS) }\end{array}$} & \multicolumn{2}{|c|}{$\begin{array}{c}\text { D } \\
\text { (Neonatal } \\
\text { Pediatric } \\
\text { Drug } \\
\text { Dose) }\end{array}$} & \multicolumn{2}{|c|}{$\begin{array}{c}\text { E } \\
\text { (Standard } \\
\text { Treatment } \\
\text { Guideline) }\end{array}$} \\
\hline & & $\mathrm{N}$ & $\%$ & $\mathrm{n}$ & $\%$ & $\mathrm{n}$ & $\%$ & $\mathrm{n}$ & $\%$ & $\mathrm{~N}$ & $\%$ \\
\hline \multirow[t]{4}{*}{ Nifudiar $^{(B)}$} & Sesuai & 3 & $3,5 \%$ & 16 & $18,8 \%$ & 11 & $12,9 \%$ & - & - & - & - \\
\hline & $\begin{array}{c}\text { Tidak sesuai } \\
\text { Tidak }\end{array}$ & 42 & $49,4 \%$ & 29 & $34,1 \%$ & 34 & $40,0 \%$ & - & - & - & - \\
\hline & $\begin{array}{c}\text { menggunakan } \\
\text { obat }\end{array}$ & 40 & $47,1 \%$ & 40 & $47,1 \%$ & 40 & $47,1 \%$ & - & - & - & - \\
\hline & Total & 85 & $100 \%$ & 85 & $100 \%$ & 85 & $100 \%$ & - & - & - & - \\
\hline Cefotaxime & Sesuai & 22 & $25,9 \%$ & 22 & $25,9 \%$ & 22 & $25,9 \%$ & - & - & - & - \\
\hline
\end{tabular}




\begin{tabular}{|c|c|c|c|c|c|c|c|c|c|c|c|}
\hline & $\begin{array}{l}\text { Tidak sesuai } \\
\text { Tidak } \\
\text { menggunakan } \\
\text { obat }\end{array}$ & 63 & $74,1 \%$ & 63 & $74,1 \%$ & 63 & $74,1 \%$ & - & - & - & $\begin{array}{l}- \\
-\end{array}$ \\
\hline & Total & 85 & $100 \%$ & 85 & $100 \%$ & 85 & $100 \%$ & - & - & - & - \\
\hline \multirow[t]{4}{*}{ Clanexy $^{\circledR}$} & Sesuai & 2 & $2,4 \%$ & - & - & 0 & 0 & 0 & 0 & - & - \\
\hline & $\begin{array}{c}\text { Tidak sesuai } \\
\text { Tidak }\end{array}$ & 4 & $4,7 \%$ & - & - & 6 & $7,1 \%$ & 6 & $7,1 \%$ & - & - \\
\hline & $\begin{array}{c}\text { menggunakan } \\
\text { obat }\end{array}$ & 79 & $92,9 \%$ & - & - & 79 & $92,9 \%$ & 79 & $92,9 \%$ & - & - \\
\hline & Total & 85 & $100 \%$ & - & - & 85 & $100 \%$ & 85 & $100 \%$ & & \\
\hline \multirow[t]{3}{*}{ Metronidazole } & Sesuai & 1 & $1,2 \%$ & 1 & $1,2 \%$ & 1 & $1,2 \%$ & 1 & $1,2 \%$ & 2 & $2,4 \%$ \\
\hline & Tidak sesuai & 3 & $3,5 \%$ & 3 & $3,5 \%$ & 3 & $3,5 \%$ & 3 & $3,5 \%$ & 2 & $2,4 \%$ \\
\hline & $\begin{array}{c}\text { Tidak } \\
\text { mengunakan } \\
\text { obat }\end{array}$ & 81 & $95,3 \%$ & 81 & $95,3 \%$ & 81 & $95,3 \%$ & 81 & $95,3 \%$ & 81 & $95,3 \%$ \\
\hline \multirow[t]{4}{*}{ Ampisillin } & Sesuai & 2 & $2,4 \%$ & 2 & $2,4 \%$ & 2 & $2,4 \%$ & 1 & $1,2 \%$ & - & - \\
\hline & Tidak sesuai & 3 & $3,5 \%$ & 0 & 0 & 3 & $3,5 \%$ & 1 & $1,2 \%$ & - & - \\
\hline & $\begin{array}{c}\text { Tidak } \\
\text { menggunakan } \\
\text { obat }\end{array}$ & 80 & $94,1 \%$ & 83 & $97,6 \%$ & 80 & $94,1 \%$ & 83 & $97,6 \%$ & - & - \\
\hline & Total & 85 & $100 \%$ & 85 & $100 \%$ & 85 & $100 \%$ & - & - & - & - \\
\hline \multirow[t]{4}{*}{ Ceftriaxone } & Sesuai & - & - & 0 & 0 & 0 & 0 & 0 & 0 & - & - \\
\hline & Tidak sesuai & - & - & 1 & $1,2 \%$ & 1 & $1,2 \%$ & 1 & $1,2 \%$ & - & - \\
\hline & $\begin{array}{c}\text { Tidak } \\
\text { menggunakan } \\
\text { obat }\end{array}$ & - & - & 84 & $98,8 \%$ & 84 & $94,8 \%$ & 84 & $98,8 \%$ & - & - \\
\hline & Total & - & - & 85 & $100 \%$ & 85 & $100 \%$ & 85 & $100 \%$ & - & - \\
\hline \multirow[t]{3}{*}{ Cefixime } & Sesuai & 0 & 0 & 1 & $1,2 \%$ & 1 & $1,2 \%$ & - & - & - & - \\
\hline & Tidak sesuai & 3 & $3,5 \%$ & 2 & $2,4 \%$ & 2 & $2,4 \%$ & - & - & - & - \\
\hline & $\begin{array}{c}\text { Tidak } \\
\text { menggunakan } \\
\text { obat }\end{array}$ & 82 & $96,5 \%$ & 82 & $96,5 \%$ & 82 & $96,5 \%$ & & & & \\
\hline \multirow[t]{4}{*}{ Cefadroxil } & Sesuai & 3 & $3,5 \%$ & 2 & $2,4 \%$ & 4 & $4,7 \%$ & - & - & - & - \\
\hline & Tidak sesuai & 2 & $2,4 \%$ & 3 & $3,5 \%$ & 1 & $1,2 \%$ & - & - & - & - \\
\hline & $\begin{array}{c}\text { Tidak } \\
\text { menggunakan } \\
\text { obat }\end{array}$ & 80 & $94,1 \%$ & 80 & $94,1 \%$ & 80 & $94,1 \%$ & - & - & - & - \\
\hline & Total & 85 & $100 \%$ & 85 & $100 \%$ & 85 & $100 \%$ & - & - & - & - \\
\hline \multirow[t]{4}{*}{ Amoxicillin } & Sesuai & 2 & $2,4 \%$ & 1 & $1,2 \%$ & 1 & $1,2 \%$ & - & - & - & - \\
\hline & Tidak sesuai & 0 & 0 & 1 & $1,2 \%$ & 1 & $1,2 \%$ & - & - & - & - \\
\hline & $\begin{array}{c}\text { Tidak } \\
\text { menggunakan } \\
\text { obat }\end{array}$ & 83 & $97,6 \%$ & 83 & $97,6 \%$ & 83 & $97,6 \%$ & - & - & - & - \\
\hline & Total & 85 & $100 \%$ & 85 & $100 \%$ & 85 & $100 \%$ & - & - & - & - \\
\hline
\end{tabular}

Keterangan:

(-): tidak menggunakan literatur

Dalam penelitian ini terapi diare akut pada pediatrik di RSUD Kraton Kabupaten Pekalongan dengan menggunakan antibiotic dapat dilihat pada Tabel VIII, menurut Amin (2015) pemberian antibiotik secara empiris jarang diindikasikan pada diare akut infeksi, karena 40\% kasus diare infeksi sembuh kurang dari 3 hari tanpa pemberian antibiotik, antibiotik diindikasikan pada pasien dengan gejala dan tanda diare infeksi, seperti demam, feses berdarah, leukosit pada feses, mengurangi ekskresi dan kontaminasi lingkungan, persisten. Akan tetapi penggunaan antibiotik pada penelitiaan ini berdasarkan anjuran dokter serta indikasi yang sesuai dengan pasien. Antibiotik yang 
paling banyak digunakan yaitu nifudiar ${ }^{\circledR}$ dan cefotaxime. Dalam penentuan kesesuaian dosis berdasarkan literatur yang digunakan, terdapat $18,8 \%$ dosis yang digunakan sesuai, sedangkan untuk cefotaxime terdapat $58,8 \%$ dosis yang digunakan sesuai.

Antibiotik nifudiar ${ }^{\circledR}$ dengan kandungan nifuroxazide merupakan antibiotik golongan nitrofuran yang bermanfaat sebagai antiseptik usus yang efektif terhadap $E$. Coli. Nitrofuran adalah antibotik yang mudah terurai dalam jaringan tubuh, cepat diabsorbsi di usus halus dan memungkinkan sedikit yang diekskresikan melalui feses, yang kemudian di hati dirombak menjadi metabolit inaktif. Nitrofuran bekerja dengan menghambat atau menganggu sistem enzim bakteri termasuk siklus asam trikarboksilat (Dewi., dkk., 2013).

Pemberian antibiotik cefotaxime merupakan antibiotik golongan cephalosporin golongan ketiga yang memiliki afinitas baik terhadap bakteri gram positif dan memiliki cakupan gram negative yang lebih luas serta aktif melawan $S$. pneumoniae. Obat ini digunakan untuk mengobati berbagai macam infeksi berat yang disebabkan oleh organisme yang resisten terhadap kebanyakan antibiotik (Zhakarian., dkk., 2018). Penelitian menurut Purnamasari (2014) menyatakan bahwa pemberian antibiotik pada kasus diare kemungkinan untuk terapi empiris, berdasarkan kemungkinan kuman penyebabnya, antibiotik yang digunakan yaitu berupa metronidazole dan kotrimoksazole.

Tabel IX. Data kesesuaian dosis analgesik pasien pediatrik diare akut di RSUD Kraton Kabupaten Pekalongan

\begin{tabular}{|c|c|c|c|c|c|c|c|c|c|c|}
\hline \multirow[t]{2}{*}{$\begin{array}{l}\text { kesesuaian } \\
\text { dosis }\end{array}$} & \multicolumn{2}{|c|}{$\begin{array}{c}\text { A } \\
\text { (Drug } \\
\text { Information } \\
\text { Handbook } \\
\text { 19 }^{\text {th }} \text { Edition) }\end{array}$} & \multicolumn{2}{|c|}{$\begin{array}{c}\text { B } \\
\text { (Informasi } \\
\text { Spesialit } \\
\text { Obat) }\end{array}$} & \multicolumn{2}{|c|}{$\begin{array}{c}\text { C } \\
\text { (MIMS) }\end{array}$} & \multicolumn{2}{|c|}{$\begin{array}{c}\text { D } \\
\text { (Neonatal } \\
\text { Pediatric } \\
\text { Drug Dose) }\end{array}$} & \multicolumn{2}{|c|}{$\begin{array}{c}\mathrm{E} \\
\text { (Standard } \\
\text { Treatment } \\
\text { Guideline) }\end{array}$} \\
\hline & $\mathbf{N}$ & $\%$ & $\mathbf{n}$ & $\%$ & $\mathbf{N}$ & $\%$ & $\mathbf{n}$ & $\%$ & $\mathbf{N}$ & $\%$ \\
\hline Sesuai & - & - & 1 & $1,2 \%$ & 9 & $10,6 \%$ & - & - & - & - \\
\hline $\begin{array}{l}\text { Tidak sesuai } \\
\text { Tidak }\end{array}$ & - & - & 11 & $12,9 \%$ & 3 & $3,5 \%$ & - & - & - & - \\
\hline $\begin{array}{c}\text { menggunakan } \\
\text { obat }\end{array}$ & - & - & 73 & $85,9 \%$ & 73 & $85,9 \%$ & - & - & - & - \\
\hline Total & - & - & 85 & $100 \%$ & 85 & $100 \%$ & - & - & - & - \\
\hline
\end{tabular}

Keterangan:

(-): tidak menggunakan literatur

Terapi diare yang digunakan selanjutnya di RSUD Kraton Kabupaten Pekalongan merupakan analgesik atau antinyeri dapat dilihat pada Tabel IX berupa sirup norages ${ }^{\circledR}$ (Metamizol Na), penentuan kesesuaian dosis sirup norages ${ }^{\circledR}$ berdasarkan literatur hanya mengunakan 2 literatur yaitu Informasi Spesialit Obat (ISO) dan MIMS. Literatur Informasi Spesialit Obat (ISO) terdapat 1 pasien $(1,2 \%)$ mendapatkan dosis yang sesuai dan terdapat 11 pasien $(12,9 \%)$ yang mendapatkan dosis yang tidak sesuai sedangkan pada literatur MIMS terdapat 9 pasien $(10,6 \%)$ mendapatkan terapi dengan dosis yang sesuai dan sebanyak 3 pasien (3,5\%) yang mendapatkan terapi dosis yang tidak sesuai. Berdasarkan hasil tersebut, dapat diartikan bahwa dalam pemberian dosis analgesik berupa sirup norages ${ }^{\circledR}$ pada anak dapat mengacu pada literatur ISO dan MIMS. Ketidaksesuaian ini disebabkan adanya dosis yang lebih dan dosis yang rendah dari dosis standar sebanyak 10-20 ml sebagai dosis tunggal maksimal 4 kali $20 \mathrm{ml}$ sehari untuk literatur MIMS sedangkan untuk literatur ISO perhitungan dosis dihitung berdasarkan berat badan pasien.

Penelitian menurut Purnamasari (2014) dalam terapi diare analgesik menggunakan parasetamol, asam mefenamat dan antalgin sedangkan penelitian menurut Septiani (2015) penggunaan analgesik dengan menggunakan Na metamizole sebanyak 1 pasien 
$(1,45 \%)$. Na metamizole merupakan golongan obat non-steroid anti inflamasi drug (NSAID) yang umum digunakan di berbagai negara yang dapat mengurangi rasa nyeri disamping itu Na metamizole juga dapat menurunkan demam pada anak yang ditandai dengan naiknya suhu tubuh. Akan tetapi penggunaan $\mathrm{Na}$ metamizole dengan jangka waktu lama dan dosis yang besar dapat menyebabkan anemia aplastik dan agranulositosis. Dosis Na metamizole yang direkomendasikan untuk anak-anak adalah $10-15 \mathrm{mg} / \mathrm{kg} / 6-8$ jam (Elmaghraby, dkk., 2014).

Tabel X. Data kesesuaian dosis terapi antiemetik pasien pediatrik diare akut rawat inap di RSUD Kraton Kabupaten Pekalongan

\begin{tabular}{|c|c|c|c|c|c|c|c|c|c|c|c|}
\hline \multirow[t]{2}{*}{ Nama obat } & \multirow[t]{2}{*}{$\begin{array}{l}\text { kesesuaian } \\
\text { dosis }\end{array}$} & \multicolumn{2}{|c|}{$\begin{array}{c}\text { A } \\
\text { (Drug } \\
\text { Information } \\
\text { Handbook } \\
\text { 19 }^{\text {th }} \\
\text { Edition) }\end{array}$} & \multicolumn{2}{|c|}{$\begin{array}{c}\text { B } \\
\text { (Informasi } \\
\text { Spesialit } \\
\text { Obat) }\end{array}$} & \multicolumn{2}{|c|}{$\begin{array}{c}\text { C } \\
(\text { MIMS) }\end{array}$} & \multicolumn{2}{|c|}{$\begin{array}{c}\text { D } \\
\text { (Neonatal } \\
\text { Pediatric } \\
\text { Drug } \\
\text { Dose) }\end{array}$} & \multicolumn{2}{|c|}{$\begin{array}{c}\text { E } \\
\text { (Standard } \\
\text { Treatment } \\
\text { Guideline) }\end{array}$} \\
\hline & & $\mathbf{N}$ & $\%$ & n & $\%$ & n & $\%$ & $\mathbf{n}$ & $\%$ & $\mathbf{N}$ & $\%$ \\
\hline \multirow{4}{*}{$\begin{array}{l}\text { Domperidone } \\
\text { sirup }\end{array}$} & Sesuai & 5 & $5,9 \%$ & 6 & $7,1 \%$ & 11 & $12,9 \%$ & 0 & 0 & - & - \\
\hline & $\begin{array}{c}\text { Tidak sesuai } \\
\text { Tidak }\end{array}$ & 25 & $29,4 \%$ & 24 & $28,2 \%$ & 19 & $22,4 \%$ & 30 & $35,3 \%$ & - & - \\
\hline & $\begin{array}{c}\text { mengunakan } \\
\text { obat }\end{array}$ & 55 & $64,7 \%$ & 55 & $64,7 \%$ & 55 & $64,7 \%$ & 55 & $64,7 \%$ & - & - \\
\hline & Total & 85 & $100 \%$ & 85 & $100 \%$ & 85 & $100 \%$ & 85 & $100 \%$ & - & - \\
\hline \multirow{4}{*}{$\begin{array}{c}\text { Injeksi } \\
\text { ondansentron }\end{array}$} & Sesuai & - & - & - & - & - & - & 15 & $17,6 \%$ & - & - \\
\hline & $\begin{array}{c}\text { Tidak sesuai } \\
\text { Tidak }\end{array}$ & - & - & - & - & - & - & 4 & $7,4 \%$ & - & - \\
\hline & $\begin{array}{l}\text { menggunakna } \\
\text { obat }\end{array}$ & - & - & - & - & - & - & 66 & $77,6 \%$ & - & - \\
\hline & Total & - & - & - & - & - & - & 85 & $100 \%$ & - & - \\
\hline
\end{tabular}

Keterangan:

(-): tidak menggunakan literatur

Terapi antiemetik dapat dilihat pada Tabel X pada kasus diare akut pediatrik yang digunakan di RSUD Kraton Kabupaten Pekalongan adalah domperidone dan injeksi ondansentron. Pada injeksi ondansentron dalam penentuan kesesuaian dosis berdasarkan literatur, hanya menggunakan literatur Neonatal and Pediatric Drug Doses karena dalam literatur Informasi Spesialit Obat (ISO) dan MIMS ondansentron digunakan untuk kasus mual dan muntah dengan tingkat yang berat pada kemoterapi sehingga tidak digunakan dalam kasus diare akut.

Penentuan dosis berdasarkan literatur yang digunakan terdapat 15 pasien $(17,6 \%)$ yang mendapatkan terapi dosis yang sesuai dan terdapat 4 pasien $(7,4 \%)$ yang mendapatkan dosis yang tidak sesuai. Pada antiemetik domperidone kesesuaian dosisnya menggunakan literatur Drug Information Handbook $19^{\text {th }}$ Edition (DIH) terdapat dosis yang sesuai sebanyak 5 pasien $(5,9 \%)$ dan sebanyak 25 pasien $(29,4 \%)$ dosis yang tidak sesuai, pada literatur Informasi Spesialit Obat (ISO) terdapat 6 pasien $(7,1 \%)$ dosis yang sesuai dan 24 pasien $(28,2 \%)$ yang mendapat dosis yang tidak sesuai, berdasarkan MIMS terdapat 11 pasien (12,9\%) yang mendapatkan dosis yang sesuai dan terdapat 19 pasien $(22,4 \%)$ yang mendapatkan dosis tidak sesuai dan literatur Neonatal and Pediatrik Drug Doses tidak terdapat dosis yang sesuai.

Penelitian menurut Septiani (2015) antiemetik yang paling banyak digunakan adalah ondansentron dan menurut Pujiastuti, dkk (2016) antiemetik yang banyak digunakan adalah injeksi ondansentron sedangkan penelitian menurut Korompis., dkk (2013) penggunaan antiemetik pada kasus diare menggunakan domperidone. Menurut Cheng (2011) mengemukakan bahwa pemberian ondansentron pada pasien diare akut 
anak berusia 6 bulan sampai 12 bulan mampu mengurangi mual dan muntah yang disertai diare (Siswidiasari dkk, 2014).

Tabel XI. Data kesesuaian dosis antipiretik pasien pediatrik diare akut di RSUD Kraton Kabupaten Pekalongan

\begin{tabular}{|c|c|c|c|c|c|c|c|c|c|c|}
\hline \multirow[t]{2}{*}{$\begin{array}{c}\text { kesesuaian } \\
\text { dosis }\end{array}$} & \multicolumn{2}{|c|}{$\begin{array}{c}\text { A } \\
\text { (Drug } \\
\text { Information } \\
\text { Handbook } \\
\text { 19 }^{\text {th }} \text { Edition) } \\
\end{array}$} & \multicolumn{2}{|c|}{$\begin{array}{c}\text { B } \\
\text { (Informasi } \\
\text { Spesialit } \\
\text { Obat) }\end{array}$} & \multicolumn{2}{|c|}{$\begin{array}{c}\text { C } \\
(\text { MIMS) }\end{array}$} & \multicolumn{2}{|c|}{$\begin{array}{c}\text { D } \\
\text { (Neonatal } \\
\text { Pediatric } \\
\text { Drug Dose) }\end{array}$} & \multicolumn{2}{|c|}{$\begin{array}{c}\mathrm{E} \\
\text { (Standard } \\
\text { Treatment } \\
\text { Guideline) }\end{array}$} \\
\hline & $\mathbf{n}$ & $\%$ & $\mathbf{n}$ & $\%$ & $\mathbf{N}$ & $\%$ & $\mathbf{n}$ & $\%$ & $\mathbf{N}$ & $\%$ \\
\hline Sesuai & 30 & $35,3 \%$ & 48 & $56,5 \%$ & 38 & $44,7 \%$ & 30 & $35,3 \%$ & - & - \\
\hline $\begin{array}{c}\text { Tidak sesuai } \\
\text { Tidak }\end{array}$ & 39 & $45,9 \%$ & 21 & $24,7 \%$ & 31 & $36,5 \%$ & 39 & $45,9 \%$ & - & - \\
\hline $\begin{array}{c}\text { menggunakan } \\
\text { obat }\end{array}$ & 16 & $18,8 \%$ & 16 & $18,8 \%$ & 16 & $18,8 \%$ & 16 & $18,8 \%$ & & \\
\hline Total & 85 & $100 \%$ & 85 & $100 \%$ & 85 & $100 \%$ & 85 & $100 \%$ & - & - \\
\hline
\end{tabular}

Keterangan:

(-): tidak menggunakan literatur

Pada terapi antipiretik dapat dilihat pada Tabel XI diare akut pada pediatrik di RSUD Kraton Kabupaten Pekalongan menggunakan parasetamol. Penentuan kesesuaian dosis parasetamol berdasarkan literatur menggunakan 4 literatur yaitu Drug Information Handbook $19^{\text {th }}$ Edition (DIH) dengan 30 pasien $(35,3 \%)$ dosis yang sesuai dan sebanyak 39 pasien $(45,9 \%)$ dosis yang tidak sesuai. Menurut literatur Informasi Spesialit Obat (ISO) terdapat 48 pasien $(56,5 \%)$ dosis yang sesuai dan 21 pasien $(24,7 \%)$ dosis yang tidak sesuai. Literatur MIMS menunjukkan bahwa sebanyak 38 pasien $(44,7 \%)$ dosis yang sesuai dan 31 pasien $(36,5 \%)$ yang tidak sesuai sedangkan pada literatur Neonatal Pediatric Drug Doses terdapat 30 pasien (35,3\%) dosis yang sesuai dan sebanyak 39 pasien $(45,9 \%)$ dosis yang tidak sesuai. Gejala demam pada anak diare akut merupakan hal yang umum, hal ini dikarenakan aktivasi invasi patogen oleh karena itu pemberian anitpiretik parasetamol merupakan hal yang sudah tepat. Pemberian parasetamol pada anak dengan dosis $10-15 \mathrm{mg} / \mathrm{KgBB} /$ dosis setiap 4-6 jam dianggap aman dan efektif (Sullivan, dkk, 2011).

Tabel XII. Data kesesuaian dosis antiulserasi diare akut pada anak di RSUD Kraton Kabupaten Pekalongan

\begin{tabular}{|c|c|c|c|c|c|c|c|c|c|c|c|}
\hline \multirow[t]{2}{*}{$\begin{array}{c}\text { Nama } \\
\text { obat }\end{array}$} & \multirow[t]{2}{*}{$\begin{array}{l}\text { kesesuaian } \\
\text { dosis }\end{array}$} & \multicolumn{2}{|c|}{$\begin{array}{c}\text { A } \\
\text { (Drug } \\
\text { Information } \\
\text { Handbook } \\
\text { 19 }^{\text {th }} \text { Edition) }\end{array}$} & \multicolumn{2}{|c|}{$\begin{array}{c}\text { B } \\
\text { (Informasi } \\
\text { Spesialit } \\
\text { Obat) }\end{array}$} & \multicolumn{2}{|c|}{$\begin{array}{c}\text { C } \\
\text { (MIMS) }\end{array}$} & \multicolumn{2}{|c|}{$\begin{array}{c}\text { D } \\
\text { (Neonatal } \\
\text { Pediatric } \\
\text { Drug Dose) }\end{array}$} & \multicolumn{2}{|c|}{$\begin{array}{c}\mathrm{E} \\
\text { (Standard } \\
\text { Treatment } \\
\text { Guideline) }\end{array}$} \\
\hline & & $\mathbf{N}$ & $\%$ & $\mathbf{n}$ & $\%$ & $\mathbf{n}$ & $\%$ & $\mathbf{N}$ & $\%$ & $\mathbf{N}$ & $\%$ \\
\hline \multirow[t]{4}{*}{ Ranitidine } & Sesuai & 0 & 0 & 1 & $1,2 \%$ & 0 & 0 & 1 & $1,2 \%$ & - & - \\
\hline & $\begin{array}{c}\text { Tidak sesuai } \\
\text { Tidak }\end{array}$ & 3 & $3,5 \%$ & 2 & $2,4 \%$ & 3 & $3,5 \%$ & 2 & $2,4 \%$ & - & - \\
\hline & $\begin{array}{c}\text { menggunakan } \\
\text { obat }\end{array}$ & 82 & $96,5 \%$ & 82 & $96,5 \%$ & 82 & $96,5 \%$ & 82 & $96,5 \%$ & & \\
\hline & Total & 85 & $100 \%$ & 85 & $100 \%$ & 85 & $100 \%$ & 85 & $100 \%$ & - & - \\
\hline \multirow[t]{4}{*}{ Antasida } & Sesuai & - & - & 2 & $2,4 \%$ & 2 & $2,4 \%$ & - & - & - & - \\
\hline & $\begin{array}{l}\text { Tidak sesuai } \\
\text { Tidak }\end{array}$ & - & - & 1 & $1,2 \%$ & 1 & $1,2 \%$ & - & - & - & - \\
\hline & $\begin{array}{c}\text { menggunakan } \\
\text { obat }\end{array}$ & - & - & 82 & $96,5 \%$ & 82 & $96,5 \%$ & - & - & - & - \\
\hline & Total & - & - & 85 & $100 \%$ & 85 & $100 \%$ & - & - & - & - \\
\hline \multirow[t]{3}{*}{ Mylanta $^{\circledR}$} & Sesuai & - & - & 1 & $1,2 \%$ & - & - & - & - & - & - \\
\hline & Tidak sesuai & - & - & 1 & $1,2 \%$ & - & - & - & - & - & - \\
\hline & Tidak & - & - & 83 & $97,6 \%$ & - & - & - & - & - & - \\
\hline
\end{tabular}




\begin{tabular}{|c|c|c|c|c|c|c|c|c|c|c|c|}
\hline & $\begin{array}{c}\text { menggunakan } \\
\text { obat }\end{array}$ & & & & & & & & & & \\
\hline & Total & - & - & 85 & $100 \%$ & - & - & - & - & - & - \\
\hline \multirow[t]{4}{*}{ Polysilen $^{\circledR}$} & Sesuai & - & - & 5 & $5,9 \%$ & - & - & - & - & - & - \\
\hline & $\begin{array}{c}\text { Tidak sesuai } \\
\text { Tidak }\end{array}$ & - & - & 0 & 0 & - & - & - & - & - & - \\
\hline & $\begin{array}{l}\text { menggunakan } \\
\text { obat }\end{array}$ & - & - & 80 & $94,1 \%$ & - & - & - & - & - & - \\
\hline & Total & - & - & 85 & $100 \%$ & - & - & - & - & - & - \\
\hline
\end{tabular}

Keterangan:

(-): tidak menggunakan literatur

Terapi antiulserasi pada pasien pediatrik diare akut di RSUD Kraton Kabupaten Pekalongan dapat dilihat pada Tabel XII menggunakan ranitidine, antasida, mylanta ${ }^{\circledR}$ dan polysilen ${ }^{\circledR}$ dapat dilihat pada Tabel XII Penentuan dosis pada antiulserasi berdasarkan literatur obat ranitidine hanya menggunakan 4 literatur. Pada literatur Drug Information Handbook $19^{\text {th }}$ Edition (DIH) dan MIMS menunjukkan bahwa dosis yang diberikan kepada pasien hanya terdapat 3 pasien $(3,5 \%)$ dosis yang tidak sesuai sedangkan menurut literatur ISO dan Neonatal Pediatric Drug Doses menunjukkan hasil yang sama yaitu terdapat 1 pasien $(1,2 \%)$ dosis yang sesuai dan terdapat 2 pasien $(2,4 \%)$ dosis yang tidak sesuai.

Penentuan dosis pada antiulserasi berdasarkan literatur obat ranitidine hanya menggunakan 4 literatur. Pada literatur Drug Information Handbook $19^{\text {th }}$ Edition (DIH) dan MIMS menunjukkan bahwa dosis yang diberikan kepada pasien hanya terdapat 3 pasien $(3,5 \%)$ dosis yang tidak sesuai sedangkan menurut literatur ISO dan Neonatal Pediatric Drug Doses menunjukkan hasil yang sama yaitu terdapat 1 pasien $(1,2 \%)$ dosis yang sesuai dan terdapat 2 pasien $(2,4 \%)$ dosis yang tidak sesuai.

Antiulserasi, antasida dalam penentuan dosis berdasarkan literatur hanya menggunakan 2 literatur yaitu Informasi Spesialit Obat (ISO) dan MIMS. Pada liteartur tersebut mempunyai hasil yang sama, terdapat 2 pasien $(2,4 \%)$ dosis yang sesuai dan terdapat 1 pasien $(1,2 \%)$ dosis yang tidak sesuai sedangkan pada antiulserasi obat mylanta ${ }^{\circledR}$ dan polysilen ${ }^{\circledR}$ dalam penentuan dosis hanya menggunakan literatur Informasi Spesialit Obat (ISO) dan MIMS. Dalam pemberian obat mylanta ${ }^{\circledR}$ terdapat 1 pasien $(1,2 \%)$ dosis yang yang diberikan sesuai dan terdapat 1 pasien $(1,2 \%)$ dosis yang tidak sesuai sedangkan untuk polysilen ${ }^{\circledR}$ dosis yang diberikan sesuai dengan literatur yang digunakan yaitu sebanyak 5 pasien $(5,9 \%)$.

Penelitian menurut Amirullah (2017) pemberian antiulserasi yang diberikan yaitu ranitidine dan penelitian menurut Septiani (2015) antiulserasi yang digunakan yaitu ranitidine. Siswidiasari dkk (2014) menyatakan bahwa pemberiaan obat antiulserasi yaitu antasida dan ranitidine merupakan pilihan yang tepat karena pada antasida merupakan obat yang berfungsi menetralkan asam lambung sehingga dapat berfungsi menghilangkan nyeri, sedangkan pada ranitidine dapat berfungsi untuk menghambat sekresi asam lambung sehingga tepat untuk mengobati pasien diare akut pada anak dengan gejala maag, peningkatan asam lambung, mual dan muntah. Dalam penelitian ini obat antiulserasi yang banyak digunakan adalah polysilen ${ }^{\circledR}$ dengan dosis yang sesuai, dimana polysilen ${ }^{\circledR}$ juga termasuk dalam golongan antasida, sehingga dapat disimpulkan bahwa pemberian polysilen ${ }^{\circledR}$ merupakan pilihan yang tepat. 
Tabel XIII. Data kesesuaian dosis obat-obat lain pada pasien pediatrik diare akut di RSUD Kraton Kabupaten Pekalongan

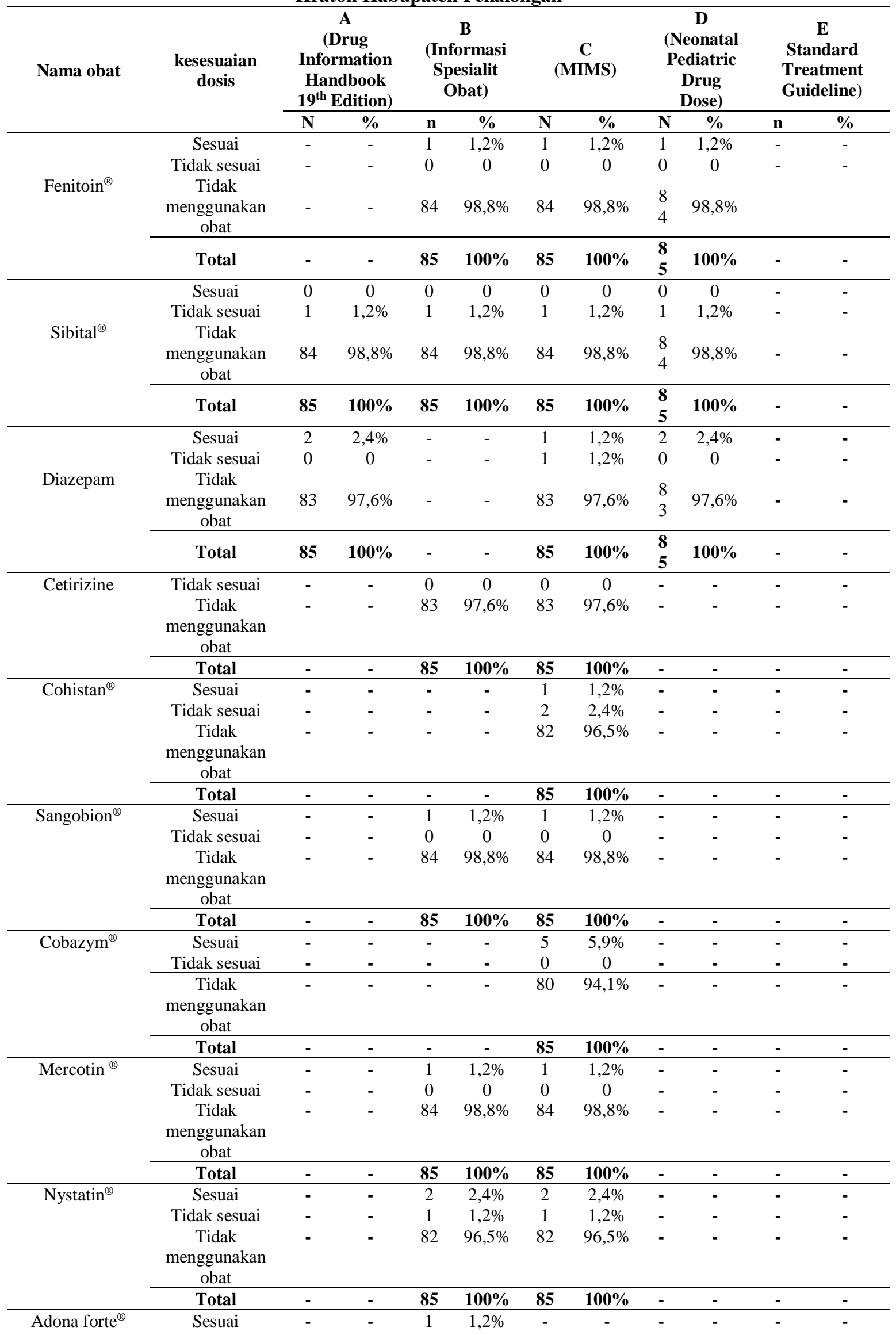




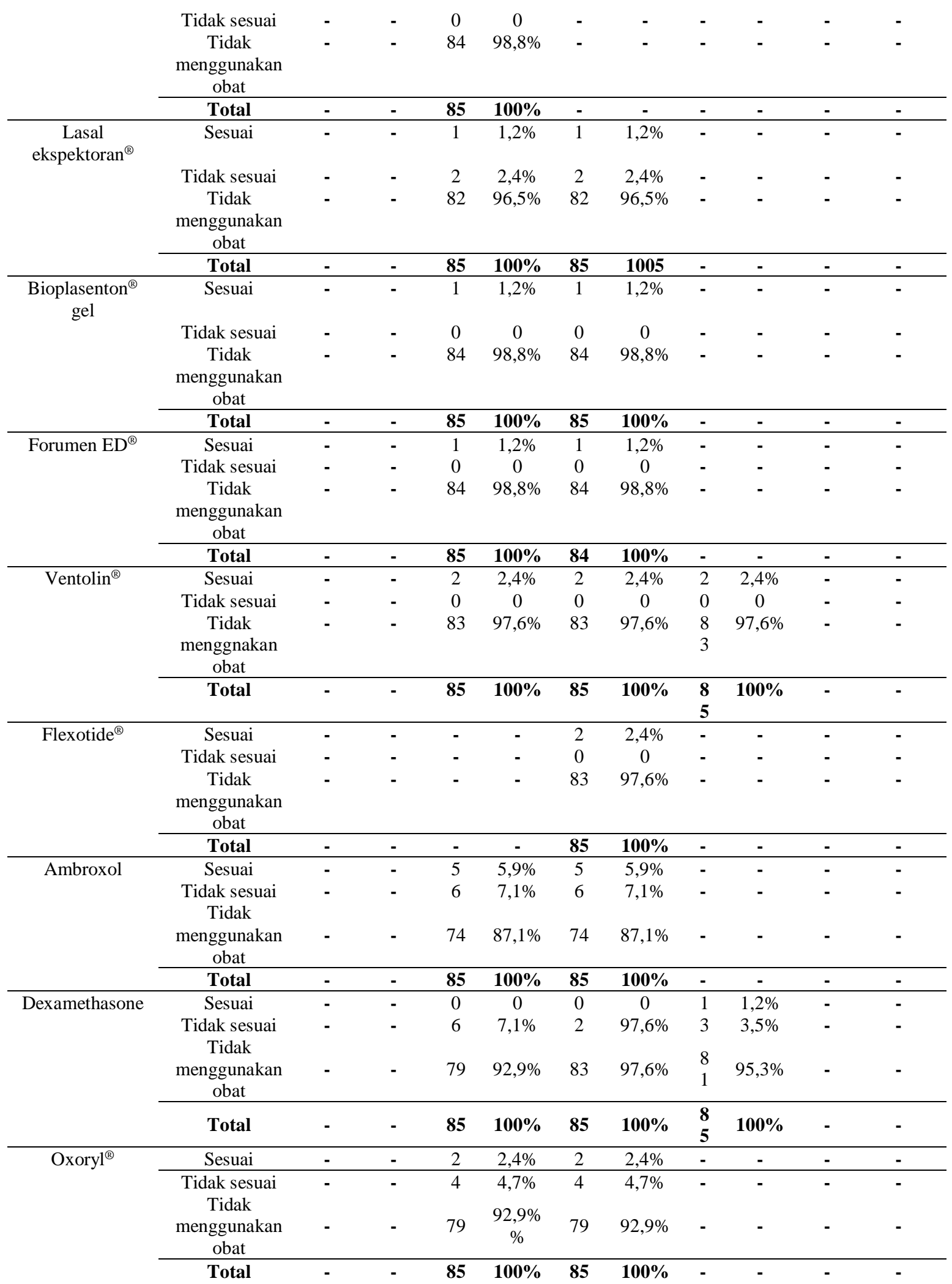

Keterangan:

(Data diolah, 2020)

(-): tidak menggunakan literatur

Berdasarkan data yang diperoleh, selain diare akut pada padiatrik terdapat juga penyakit penyerta pada pasien pediatrik diare akut di RSUD Kraton berupa kejang, 
batuk pilek, alergi, ISPA, anemia, perdarahan, serta gangguan kulit. Terapi penyakit penyerta atau terapi non-diare akut pasien pediatrik di RSUD Kraton Kabupaten Pekalongan yang diberikan kepada pasien dapat dilihat pada Tabel XIII.

Demam pada anak sering disebabkan karena adanya infeksi saluran pernapasan atas, otitis media, pneumonia, gastroenteritis dan infeksi saluran kemih. Kenaikan suhu tubuh yang tinggi (suhu rectal lebih dari $38^{\circ} \mathrm{C}$ ) yang disebabakan oleh suatu proses ekstrakranial dapat menyebabkan terjadinya kejang demam. Kejadian kejang demam pada kasus ini terjadi pada anak, pada anak mencapai 2-4\% pada usia 6 bulan7 tahun dan $80 \%$ pada usia 1-2 tahun (Kakalang., dkk, 2016).

Menurut Yunita., dkk (2016) menyatakan bahwa secara umum kejang memiliki prognosis yang baik, namun sekitar 30-35\% anak dengan kejang demam pertama akan mengalami kejang berulang. Faktor yang berhubungan dengan adanya kejang berulang antara lain riwayat kejang demam dalam keluarga, usia kurang dari 12 bulan, temperature yang rendah saat kejang, dan cepatnya kejang setelah demam. Dalam penelitian ini kejang demam disebabkan karena panas atau demam yang terlalu tinggi dan karena adanya riwayat kejang pada anak yang mengakibatkan terjadinya kejang berulang. Adapun terapi untuk penanganan kejang di RSUD Kraton diberikan antikonvulsan berupa fenitoin ${ }^{\circledR}$, sibital ${ }^{\circledR}$ serta diazepam, penentuan kesesuaian dosis dari obat antikonvulsan berdasarkan literatur yang digunakan, untuk obat sibital ${ }^{\circledR}$ (phenobarbital natrium) dosis yang diberikan tidak sesuai dengan literatur yang digunakan, untuk obat diazepam dosis yang sesuai sebanyak $2,4 \%$, dan untuk fenitoin dosis yang diberikan sesuai.

Batuk dan pilek merupakan penyakit yang menyerang baik anak maupun dewasa. Pada anak batuk dan pilek menyerang pada usia dibawah 6 tahun. Dalam kasus ini batuk dan pilek menyerang anak usia 2-14 tahun. Batuk dan pilek disebabkan oleh rhinovirus, adenovirus, virus influenza, enterovirus, dan coronavirus. Obat batuk umumnya memiliki kandungan antihistamin, dekongestan, antitusif, ekspektoran dan analgesik antipiretik (Soedibyo., dkk, 2013).

Terapi pengobatan untuk batuk pilek diberikan lasal expektoran ${ }^{\circledR}$, ambroxol, cohistan $^{\circledR}$, oxoryl ${ }^{\circledR}$ sirup serta mercotin ${ }^{\circledR}$. Penentuan kesesuaian dosis berdasarkan literatur yang digunakan, untuk lasal ekspektoran terdapat $1,2 \%$ dosis yang sesuai, amboroxol sebanyak 5,9\% dosis yang sesuai, $\operatorname{cohistan}^{\circledR}$ dan mercotin ${ }^{\circledR}$ sebanyak $1,2 \%$ dosis yang sesuai dan oxoryl ${ }^{\circledR}$ sirup sebanyak $2,4 \%$ dosis yang sesuai.

Pada penelitian ini, pasien pediatrik diare akut juga disertai dengan gangguan sistem pernapasan berupa infeksi saluran pernapasan akut (ISPA). ISPA merupakan penyakit yang sangat umum terjadi pada anak-anak dengan gejala batuk, pilek, demam (panas) atau gejala tersebut muncul secara bersamaan (Wardhani., dkk, 2018). Pada penelitian ini terapi untuk ISPA dengan menggunakan ventolin ${ }^{\circledR}$ nebul dan flexotide ${ }^{\circledR}$ nebul. Ventolin ${ }^{\circledR}$ merupakan obat yang mengandung salbutamol yaitu obat saluran napas yang termasuk agonis adrenoreseptor beta-2 selektif kerja pendek obat ini bekerja dengan cara merangsang secara selektif reseptor beta-2 adrenergik terutama pada otot bronkus sehingga menyebabkan terjadinya bronkodilatasi karena otot brokuns relaksasi, sedangkan flexotide ${ }^{\circledR}$ mengandung fluticasone propionate 0,5 $\mathrm{mg} / 2 \mathrm{ml}$, obat ini digunakan untuk mengobati asma ringan, sedang dan berat pada dewasa dan anak kurang dari 1 tahun (Yuliana \& S.I Agustina, 2016).

Penentuan dosis obat ventolin ${ }^{\circledR}$ dan flexotide ${ }^{\circledR}$ berdasarkan literatur yang digunakan, dosis yang diberikan kepada pasien di RSUD Kraton Kabupaten Pekalongan 2,4\% sesuai. Penelitian menurut Astuti., dkk (2019) dalam penanganan gangguan pernapasan yaitu dengan menggunakan flexotide ${ }^{\circledR}$ dan Ventolin ${ }^{\circledR} 1$ ampul serta tambahan bisolvon cair guna untuk mengencerkan dahak. Pada penelitian ini untuk terapi ISPA dengan menggunakan sediaan nebulizer. Nebulizer merupakan alat yang digunakan untuk merubah obat-obat bronkodilator dari bentuk cair kebentuk aerosol atau partikel yang sangat halus, aerosol sangat bermanfaat untuk organ paru apabila dihirup atau dikumpulkan di organ paru. Efek terapi ini untuk mengembalikan 
kondisi spasme bronkus, mengurangi sesak napas, relaksasi, mengencerkan dahak, melancarkan saluran pernapasan dan melembabkan saluran napas. Terapi ISPA menggunakan nebulizer merupakan terapi yang tepat dan paling efektif dari obat oral maupun intravena, karena langsung dihirup masuk ke paru-paru (Astuti., dkk., 2019).

Pemberian bioplasenton ${ }^{\circledR}$ gel dalam terapi diare akut digunakan untuk meredakan panas pada anus akibat frekuensi BAB yang banyak, penggunaan bioplasenton ${ }^{\circledR}$ gel pada penelitian ini dengan cara mengoleskan secara tipis-tipis di sekitar anus atau bagian luar anus, sedangkan pada pemberian Forumen $\mathrm{ED}^{\circledR}$ yang mengandung natrium docusate $5 \mathrm{mg} / \mathrm{ml}$ dapat digunakan untuk membersihkan kotoran telinga yang diberikan dengan cara teteskan sediaan secukupnya ke dalam telinga, sedangkan pada pemberian nystatin ${ }^{\circledR}$ atau kandistatin dalam penelitian ini digunakan untuk mengobati gangguan infeksi jamur pada rongga mulut. Obat ini diberikan karena pasien mengeluhkan adanya sariawan pada mulutnya, obat ini dapat menghambat pertumbuhan jamur, penentuan dosis berdasarkan literatur yang digunakan, nystatin ${ }^{\circledR}$ terdapat $2,4 \%$ dosis yang sesuai (Informasi Spesialit Obat, 2018).

Pemberiaan adona forte ${ }^{\circledR}$ tablet digunakan untuk mengatasi perdarahan dikulit, membran mukosa dan membran internal, perdarahan di funfus mata, perdarahan ginjal, perdarahan yang disebabkan menurunnya resistensi kapiler seperti perdarahan paska atau selama operasi. Pada penelitian ini adona forte ${ }^{\circledR}$ diberikan kepada pasien dikarenakan pasien mempunyai riwayat kepala sering dipukul sendiri sehingga mengakibatkan terjadinya mimisan (epistaksis). Penentuan dosis adona forte ${ }^{\circledR}$ berdasarkan literatur terdapat $1,2 \%$ dosis yang diberikan sesuai (Infromasi Spesialit Obat, 2018).

Menurut Limen., dkk (2013) menyatakan bahwa epistaksis merupakan keluarnya darah dari hidung yang penyebabnya bisa secara lokal maupun sistemik. Penyakit ini banyak dijumpai pada anak maupun usia lanjut. Distribusi umur penderita epistaksis biasanya terjadi pada usia $\leq 20$ tahun dan $\geq 40$ tahun. Penyebab lokal epistaksis diakibatkan oleh sinusitis kronis, benda asing, iritan dan trauma sedangkan penyebab sistemik berupa hipertensi, leukemia, sirosis hati dan penggunaan obat-obatan.

Pada penelitian ini penyakit penyerta selanjutnya pada kasus diare anak di RSUD Kraton Kabupaten Pekalongan berupa anemia, terapi yang diberikan yaitu sangobion ${ }^{\circledR}$ dan cobazym $^{\circledR}$. Dalam penentuan kesesuaian dosis berdasarkan literatur yang digunakan, terdapat $1,2 \%$ dosis yang sesuai untuk obat sangobion ${ }^{\circledR}$ sedangkan untuk cobazym $^{\circledR}$ sebanyak $5,9 \%$ dosis yang diberikan sesuai.

Menurut Sirajuddin, dkk (2015) menyatakan bahwa anemia pada anak akan berdampak pada menurunnya kemampuan dan konsentrasi belajar, mengganggu pertumbuhan baik sel tubuh maupun sel otak sehingga menimbulkan gejala muka pucat, letih, lesu, dan cepat lelah sehingga dapat menurunkan kebugaran dan prestasi belajar. Anemia defisiensi dapat dipengaruhi oleh kebutuhan tubuh meningkat, akibat mengidap penyakit kronis, kehilangan darah karena menstruasi, dan infeksi parasit.

Pada pemberian cetirizine sirup dan dexamethasone digunakan untuk mengatasi alergi rhinitis. Dalam penentuan kesesuaian dosis berdasarkan literatur yang digunakan, terdapat $2,4 \%$ dosis yang sesuai untuk cetirizine sirup sedangkan untuk dexamethasone diberikan melalui intravena dengan kesesuaian dosis sebanyak 1,2\% dosis yang sesuai dan 7,1\% dosis yang diberikan tidak sesuai. Ketidaksesuaian dosis ini disebabkan adanya dosis yang lebih atau rendah dari dosis standar pada literatur yang digunakan yaitu $0,5 \mathrm{mg} / \mathrm{tab}$ atau $5 \mathrm{mg} / \mathrm{ml}$ injeksi, untuk anak $\leq 1$ tahun $0,1-0,25$ mg, anak 1-5 tahun sebanyak 0,25-1 mg dan anak 6-12 tahun 0,25-2 mg untuk literatur ISO sedangkan literatur NPDD sebanyak $0,25-0,5 \mathrm{mg} / \mathrm{kg}$ dosis setiap 12 jam.

Penelitian ini tidak semua golongan obat yang diberikan kepada pasien memiliki dosis sesuai berdasarkan literatur yang digunakan, adapun beberapa hal penyebab ketidaksesuaian dosis yang diberikan kepada pasien terjadi karena adanya pembulatan dosis baik yang melebihi ataupun yang dibawah dosis lazim dan ketidaksesuaian dosis berdasarkan berat badan, umur, ataupun disebabkan karena perbedaan referensi yang 
digunakan antara peneliti ataupun petugas medis di RSUD Kraton Kabupaten Pekalongan (Pertiwi., dkk, 2017).

\section{KETERBATASAN PENELITIAN}

Adapun keterbatasan dalam penelitian ini berupa dalam pengambilan data rekam medik yaitu terdapat data yang sulit terbaca dan kurang jelas, berhentinya penelitian cukup lama dan penelitian yang dibatasi jumlah peneliti dalam pengambilan data selama pandemi covid-19, Jenis penelitian yang digunakan berupa penelitian bersifat retrospektif dimana terdapat kekurangan dalam hal penyesuaian terapi pengobatan dengan outcome pasien.

\section{KESIMPULAN}

Dari hasil penelitiaan yang telah dilakukan dapat disimpulkan bahwa: Evaluasi kesesuaian dosis pada penderita pediatrik diare akut di RSUD Kraton Kabupaten Pekalongan yaitu: Kesesuaian dosis elektrolit berdasarkan literatur yang digunakan sebanyak $100 \%$ sesuai, kesesuaian dosis zink sebanyak 8,2\% untuk literatur DIH, 68,2\% untuk literatur ISO, MIMS dan Standard Treatment Guideline, dan sebanyak 9,4\% untuk literatur Neonatal Pediatric Drug Dose, kesesuaian dosis probiotik berdasarkan literatur ISO dan MIMS sebanyak $100 \%$ sesuai, kesesuaian dosis antibiotik berdasarkan literatur yang digunakan, antibiotik yang paling banyak digunakan di RSUD Kraton Kabupaten Pekalongan berupa nifudiar $^{\circledR}$ dan cefotaxime. Pada obat nifudiar sirup terdapat $18,8 \%$ dosis yang diberikan sesuai sedangkan pada cefotaxime terdapat $58,8 \%$ dosis yang sesuai, kesesuaian dosis analgesik berupa norages ${ }^{\circledR}$ sirup berdasarkan literatur ISO sebanyak $1,2 \%$ dosis yang sesuai sedangkan berdasarkan MIMS sebanyak 10,6\% dosis yang sesuai, kesesuaian dosis antiemetik berupa domperidone sirup berdasarkan literatur DIH sebanyak 5,9\%, literatur ISO sebanyak $7,1 \%$ dan pada literatur MIMS sebanyak 12,9\% dosis yang sesuai, sedangkan pada literatur Neonatal Pediatric Drug Dose tidak ada dosis yang sesuai, kesesuaian dosis antipiretik berupa parasetamol berdasarkan literatur yang DIH dan Neonatal Pediatric Drug Dose terdapat $35,3 \%$ dosis yang sesuai, pada literatur ISO sebanyak $56,5 \%$ dan pada literatur MIMS sebanyak 44,7\% dosis yang sesuai, kesesuaian dosis antiulserasi berupa polysilen ${ }^{\circledR}$ berdasarkan literatur MIMS terdapat 5,9\% dosis yang sesuai.

\section{UCAPAN TERIMAKASIH}

Syukur Alhamdulillah peneliti panjatkan kehadirat Allah SWT, berkat kelimpahan rahmat dan hidayah-Nya penelitian ini dapat terselesaikan. Peneliti mengucapkan terimakasih kepada Universitas Muhammadiyah Pekajangan Pekalongan, BAPPEDA Kabupaten Pekalongan, RSUD Kraton Kabupaten Pekalongan, kedua orang tua dan seluruh sahabat yang telah membantu peneliti dalam meyelesaiakan penelitian ini.

\section{DAFTAR PUSTAKA}

Anonim. (2010). Standard Treatment Guidelines Sixth Edition. Ministry of Health: Republic of Ghana

Amin, L.Z. (2015). Tatalaksana Diare Akut. Continuing Medical Education. Jakarta: halaman 504-508.

Amirullah. (2015). Metode Penelitian Manajemen. Malang: Bayumedia Publishing Malang

Amirulah, Rifki. (2017). Evaluasi Penggunaan Obat Antidiare Pada Pasien Balita Rawat Inap Di Rumah Sakit Umum Daerah Karanganyar Tahun 2015, Karya Tulis Ilmiah, Fakultas Farmasi, Universitas Setia Budi Surakarta.

Ardyanti, Aprilia T. (2018). Evaluasi Rasionalitas Penggunaan Antibiotik Pada Pasien Anak Diare Akut Di Instalasi Rawat Inap Rsud Kardinah Kota Tegal Periode 2016, Skripsi, Fakultas Farmasi, Universitas Setia Budi Surakarta.

Astuti, W.T., Emah, M., dan Nasihatut, D. (2019). Penerapan Terapi Inhalasi Nebulizer Untuk Mengatasi Bersihan Jalan Napas Pada Pasien Bronkopneuminia. Jurnal keperawatan. Volume 5 (02). 
Dewi, e., Khairil., dan Mudatsir. (2013). Analsisi Potensi Antibakteri The Rosela Terhadap Paparan Entheropathogenic Escherichia Coli (EPEC) Pada Mencit. Jurnal Kedokteran Syiah Kuala. Volume 13 (02)

El-Ashry, Marwa., Haidy Usama., dan Yasmin El-Mesallamy. (2014). Neonatal and Pediatric Drug Doses 2014. Clinical Pharmacy Departement. Embaba El-A’M Hospital.

Elmaghraby, N.A., Ahmed, K., Mohamed, H.M., dan Mohamed, A.E. (2014). Comparasion the Antipyretic Effect of Paracetamol, Metamizole Sodium and Diclofenac Potassium in Breaking Down Fever In Children. Journal of American Science. Volume 10 (09).

Kakalang, J.P., Nurhayati, M., dan Jeanette, I.Ch. M. (2016). Profil Kejang Demam di Bagian Ilmu Kesehatan Anak RSUP Prof. Dr. R. D. Kanadou Manado Periode Januari 2014-Juni 2016. Jurnal e-clinic. Volume 4 (02).

Kasim, Fauzi., dan Yulia, Trisna. (2016). Informasi Spesialite Obat Indonesia. Jakarta: PT. ISFI Penerbitan.

Korompis, F., Heedy T., dan Lily, R.G. (2013). Studi Penggunaan Obat Pada Penderita Diare Akut Di Instalasi Rawat Inap BLU RSUP PROF. DR. R. D. Kandou Manado Periode Januari-Juni 2012. Jurnal Ilmiah Farmasi. Volume 2 (01).

Kian, H.C., Leizel A.D., Enaria., Shirley, E.V.T., et., al. (2019). MIMS Drug Reference Concise Prescribing Information 143th Edition 2019. Jakarta: PT. Medidata Indonesia.

Kustantinah, Abdul M., Nur R.P., Fachriah S., Sri B.L., Retnosari A., Adji P., dkk. (2009). Pedoman Pelayanan Kefarmasian untuk Pasien Pediatri. Jakarta: Departemen Kesehatan RI.

Lacy, Charles F., Lora, L.A., Norton, P.G.M., dan Leonardo, L.L. (2011-2012). Drug Information Handbook with International Trade Names Index 20th Ed. American Phramacist Asosiation. Lexi-Comp's Reference Handbook.

Limen, M. P., Ora, P., dan Ronny, T. (2013). Epistaksis di Poliklinik THT-KL BLU RSUP Prof DR. R. D. Kanadou Manado Periode Januari 2010-Desember 2012. Jurnal eBiomedik. Volume 1 (01).

Pertiwi, L., Dimas, P.N., dan Inayah. (2017). Gambaran Farmakoterapi Diare Akut Pada Anak Di Puskesmas Simpang Tiga Kota Pekanbaru Periode 1 Januari-31 Desember 2015. JOM FK. Vol 4 (1).

Purnamasari, N.D., Arie R.H., dan Tanti Azizah. (2014). Evaluasi Terapi Diare Pada Pasien Anak Di Puskesmas Nguter Kabupaten Sukoharjo Tahun 2012, Skripsi, Fakultas Farmasi, Universitas Muhammadiyah Surakarta.

Rahmi, D., dan Pramita, G. (2015). Laporan Kasus Berbasis Bukti Manfaat Pemberiaan Probiotik Pada Diare Akut. Sari pediatri. Volume 17 (01).

Riskesdas. (2007). Riset Kesehatan Dasar. Jakarta: Badan Penelitian Dan Pengembangan Kesehatan Kementerian Kesehatan RI.

Septiani, Sundari., dan Zakky Cholisoh. (2015). Evaluasi Penggunaan Obat Pada Pasien Balita Terkena Diare Pada Pasien Rawat Inap Di Rumah Sakit X Pada Tahun 2014, Skripsi, Fakultas Farmasi, Universitas Muhammadiyah Surakarta.

Sirajuddin, S., dan Masni. (2015). Kejadian Anemia Pada Siswa Sekolah Dasar. Jurnal Kesehatan Masyarakat Nasional. Volume 9 (03).

Siswidiasari, A., Ketut, W.A., dan Sagung., C.Y. (2014). Profil Terapi Obat Pada Pasien Rawat Inap Dengan Diare Akut Pada Anak di Rumah Sakit Umum Negara. Jurnal Kimia. Volume 8 (2).

Soedibyo, S., Arie, Y., dan Wardhana. (2013). Profil Penggunaan Obat Batuk Pilek Bebas pada Pasien Anak dibawah Umur 6 Tahun. Sari Pediatri. Volume 14 (06).

Sullivan, J.E., dan Henry, C.F. (2011). Clinical Report Fever and Antipyretic Use in Children. American Academy of Pediatrics, 127. 580-587.

Wardhani, A.K., Siti, R., dan Seviana, R. (2018). Faktor-Faktor yang Berhubungan Dengan Gejala Gangguan System Pernapasan Akibat Paparan Debu Silika (Sio2) Pada Area 
Hand Moulding II, Hand Moulding III, Fetling dan Melting Pekerja Pabrik 1 Pengecoran PT Barata Indonesia. Jurnal Kesehatan. Volume 11 (01).

World Gastroenterology Organisation Global Guidelines. (2012). Acute diarrhea in adults and children: a global prespective. WGO Press

World Gastroenterology Organisation Global Guidelines. (2011). Probiotics and Prebiotics. J Clin Gastroenterol. Volume 46 (06).

Yuliana, A.R dan S.I Agustina. (2016). Terapi Nebulizer Mengurangi Sesak Nafas Pada Serangan Asma Bronkiale Di Ruang Igd Rsud Dr. Loekmono Hadi Kudus.

Yunita, V.E., Afdal., Iskandar, S. (2016). Gambaran Faktor yang Berhubungan Dengan Timbulnya Kejang Demam Berulang Pada Pasien yang Berobat di Poliklinik Anak RS. DR. M. Djamil Padang Periode Januari 2010-Desember 2012. Jurnal Kesehatan Andalas. Volume 5 (03).

Zhakarian, G., Dewa. M. S., dan Ni, N. D. F. (2018). Pemberian Antibiotik Cefotaxime Dengan Konsentrasi Sublethal Pada Isolate Klebsiella Pnuemoniae Yang Resisten Terhadap Apicillin Menginduksi Multi Drug Resisten (MDR). Intisari Sains Medis. Volume 9 (01) halaman 64-70. 
